\title{
36 \\ Constitutional Dimensions of Law Reform
}

\author{
Gabrielle Appleby and Anna Olijnyk ${ }^{1}$
}

\section{Introduction}

In Australia, law reform occurs in the shadow of limits imposed by the Constitution. This chapter engages with two aspects of the relationship between law reform and constitutional limits. First, how do constitutional limits influence parliaments' consideration of law reform proposals? Second, what law reforms are needed in order to allow parliaments to engage in proper deliberation about constitutional limits?

Most proposed legislation falls well within constitutional boundaries. In a small (but not negligible) number of cases it will be unclear whether proposed legislation falls within the parliament's legislative power. This is most likely when parliaments are asked to pass innovative legislative proposals to address emerging challenges and priorities such as national security, environmental and social issues. For example, when the federal parliament considered in 2012 a proposed amendment to the Marriage Act 1961 (Cth) that would have allowed same-sex marriage,

1 Associate Professor, UNSW Law (Appleby) and Lecturer, Adelaide Law School (Olijnyk). The research in this chapter is supported by Australian Research Council Discovery Project 140101218 , 'Law, Order and Federalism'. 
there was considerable constitutional uncertainty about whether the Commonwealth's power to make laws with respect to 'marriage' extended that far. ${ }^{2}$

In Part II of this chapter, we explore the way in which Australian parliaments ought to take into account constitutional limits when considering law reform proposals that require legislative development in uncharted constitutional waters. In Part III we consider current parliamentary practice and the ways that practice falls short of our ideal conception. In the final part of the chapter we propose two specific law reforms needed to help parliamentarians meet their obligations to deliberate about constitutionality: the more frequent release of advice provided by the Solicitor-General to the parliament, and the creation of a role for a constitutional law specialist to advise parliament about the constitutional limits of its legislative power.

\section{Parliament's Obligation to Deliberate about Constitutionality}

What should parliamentarians do when deliberating about a proposed law at the boundaries of established constitutional principles? The option of seeking an advisory opinion from the High Court was foreclosed in 1921. ${ }^{3}$ Another option is for parliamentarians to defer to the Executive's assurances that legislation is likely to be constitutionally valid and not consider the issue separately for themselves. While this is often the current practice, we think it is unsatisfactory.

From a purely practical point of view, parliament has an identifiable selfinterest in considering questions of constitutional validity because its own legislative goal will be frustrated if legislation is held invalid. But there are more constitutionally fundamental reasons why parliamentarians have a responsibility to consider the constitutionality of proposed legislation. Like all officials in a public institution operating within a constitutional democracy, parliamentarians have obligations under the rule of law.

2 For a discussion of the debate about constitutionality on this issue, see Gabrielle Appleby and Adam Webster, 'Parliament's Role in Constitutional Interpretation' (2013) 37 Melbourne University Law Review 255.

3 Re Judiciary and Navigation Acts (1921) 29 CLR 257. 
This obligation is reflected in the parliamentary oath. ${ }^{4}$ The responsibility of a parliament to consider the constitutional validity of its legislative actions is underscored by the reality that many enactments will go unchallenged (which might happen for a variety of reasons, from lack of justiciability to lack of a willing plaintiff with standing). If parliament has not seriously considered whether its actions fall within constitutional limits, the rule of law is at risk of being undermined. In Australia, this aspect of parliament's role has not attracted significant academic attention to date. ${ }^{5}$

Constitutionality is not, of course, the only matter parliament should consider when deliberating about proposed legislation. As democratic institutions, parliaments are responsible to the electorate and thus have a strong imperative to pass legislation that responds to the desires, and serves the needs, of the community. We noted previously that constitutional uncertainty often arises when parliament is experimenting with novel legislative approaches to new social and economic conditions and expectations. If parliamentarians only passed legislation when certain it would withstand constitutional challenge, this would rule out many legislative options that might be preferred from a policy point of view. Additionally, challenges to the validity of laws that have been enacted at the edge of constitutional certainty can clarify and develop constitutional principles. ${ }^{6}$

Therefore, we do not argue that parliament has an obligation to avoid potential constitutional invalidity of legislative reforms as an absolute or overriding obligation. But nor do we argue that constitutionality is irrelevant. Instead, we argue that when the constitutional position is uncertain, constitutionality should be one of several factors parliamentarians weigh up as part of a holistic deliberative process about

4 See, for example, the oath and affirmation for Commonwealth parliamentarians in the Schedule to the Australian Constitution.

5 The exceptions being Daryl Williams, 'The Australian Parliament and the High Court: Determination of Constitutional Questions' in Charles Sampford and Kim Preston (eds), Interpreting Constitutions: Theories, Principles and Institutions (Federation Press, 1996) 203; Andrew Lynch and Tessa Meyrick, 'The Constitution and Legislative Responsibility' (2007) 18 Public Law Review 153; Gabrielle Appleby and Adam Webster, 'Parliament's Role in Constitutional Interpretation' (2013) 37 Melbourne University Law Review 255.

6 Examples of constitutional challenges advancing our understanding of constitutional principles include Commonwealth v Tasmania ('Tasmanian Dam Case') (1983) 158 CLR 1); Momcilovic v The Queen (2011) 245 CLR 1; Commonwealth v ACT (2013) 250 CLR 441; and New South Wales v Commonwealth ('Work Choices Case') (2006) 229 CLR 1. 
the merits and risks of the proposal. We emphasise that this applies where there is uncertainty, and ought not to apply where there is consensus among constitutional experts that the proposal is constitutionally invalid. ${ }^{7}$ Parliamentarians should evaluate the risk of constitutional invalidity: how certain is the relevant body of constitutional law? How close to the line does the proposed law fall? What will be the consequences if the law is passed and later held invalid? For example, will individuals have suffered non-reversible infringements of their rights? Will significant public expense be incurred in the constitutional challenge? Against this risk, parliamentarians should weigh the importance of the policy objective being pursued. Some policies may be so crucial they can justify a high degree of constitutional risk. Parliamentarians should also examine how the design of a proposed law affects its constitutionality. Can the design be changed to reduce the constitutional risk? If so, will this compromise the policy goal? An important part of the constitutional deliberation will be the consideration and weighing of alternatives by reference to constitutional rules and principles.

Undoubtedly the Executive has its own constitutional obligations to engage with constitutional limits in the development of law reform proposals. But this does not relieve parliament of its obligation. In our conception of parliament's proper role in constitutional interpretation, parliament's contribution is different from that of the Executive. Different parties, and different members of parliament, will have different views about the importance of a given policy goal and the merits of specific legislative design features. Different individuals will be more or less risk averse and may take different views about the constitutional position. In a democracy, it is appropriate that these differences form part of the process of deliberating about proposed legislation. Further, public legislative debate about the constitutionality of proposed legislative action, and a rigorous and detailed consideration of alternative legislative design that might diminish constitutional issues, may prove helpful in subsequent judicial review of the enactment. This is particularly likely when the relevant constitutional principles turn on proportionality-style analyses, in which the availability of viable alternative policy measures is relevant to validity. ${ }^{8}$

7 See further discussion in Appleby and Webster, above n 5, 292-94.

$8 \quad$ McCloy v New South Wales (2015) 89 ALJR 857; Betfair Pty Ltd v WA (2008) 234 CLR 418. 


\section{Current Practice ${ }^{9}$}

When Australian parliamentarians consider the constitutionality of proposed legislation, the debate tends to assume a superficial and binary character. Nuanced weighing of constitutional risk and careful consideration of how legislative design plays into that risk are almost entirely absent. This is at least in part attributable to the lack of constitutional assistance, in the form of professional legal advice, available to parliamentarians, particularly non-government members and backbenchers.

While sometimes acknowledging uncertainty about constitutional limits, government members assure parliament the law is likely to be valid. These assurances will often be provided by reference to legal advice obtained by the government - often by the government's most senior legal adviser, the Solicitor-General - but this advice will not be released to parliament. When parliamentarians simply rely upon the government's assurances that it has received advice relating to constitutional validity, they have insufficient information to engage with the questions that we have asserted are part of robust, responsible constitutional scrutiny. They are unable to gauge the level of risk associated with a proposal, or consider the constitutional risk associated with alternative ways of achieving the policy objective. Nor are the reasons for taking the constitutional risk made public.

Non-government members of parliament will often raise the risk of invalidity, not as a genuine issue that relates to their constitutional responsibilities, but as a reflexively oppositional political manoeuvre. Without a clear conception of parliament's responsibilities to the Constitution and appropriate processes and mechanisms in place to achieve these, the risk is that parliamentarians will employ the Constitution for reasons that have little to do with either constitutional or democratic responsibility. By reference to the 2012 attempt to amend the Marriage Act 1961 (Cth) to achieve marriage equality and the debates this raised around the scope of the Commonwealth's marriage power, Gabrielle Appleby and Adam Webster identified two fundamental concerns in this respect. ${ }^{10}$ The first was that constitutional uncertainty might be

9 As there is not scope in this chapter for a detailed explanation of current parliamentary practice around constitutional engagement in the legislative process, we have instead outlined our conclusions from our previous research using case studies of parliamentary deliberation at both state and Commonwealth level. See Appleby and Webster, above n 5.

10 Ibid. 
used as a 'shield': parliamentarians not wishing to engage with divisive policy issues that raise difficult moral questions might simply avoid such a political quagmire by claiming constitutional uncertainty as a reason not to act. The second was that constitutional uncertainty might be used as a 'sword' to kill off the proposed reform: parliamentarians might claim that, because of the constitutional uncertainty, parliament should not act but rather the reform should be passed as a constitutional amendment by referendum under s 128 of the Constitution. The difficulties of achieving constitutional change under s 128 are well known. An argument that a reform ought to be sent to referendum is less likely to be an authentic appeal to popular sovereignty than an attempt to ensure the reform's ultimate failure. As both a 'sword' and a 'shield', constitutionality can detract from the quality of the debate about the policy merits of proposed legislation.

The cost of failure to engage in robust constitutional scrutiny is not only the loss of an opportunity for parliament to fulfil its constitutional and democratic obligations as a forum for debate about public policy. It may also lead to the adoption of less-than-optimal policy choices. When nongovernment parliamentarians become aware of a constitutional issue but lack the expertise or advice to assess the risk, they may urge the parliament to take a constitutionally 'conservative' approach. They are unable to engage with more sophisticated questions such as level of constitutional risk, and possible alternatives that might achieve the same objective. It becomes politically prudent for the government to take a constitutionally safe course. This can mean eschewing options that would better achieve the policy goal, and that may be valid, but are less constitutionally certain. ${ }^{11}$ Mark Tushnet describes this inappropriate domination of constitutional norms over policy considerations as 'policy distortion'. ${ }^{12}$

Constitutional validity, and the desire to simply implement what are known to be valid constitutional regimes, might undermine the government and parliament's engagement with the policy merits of a proposal: whether it

11 Examples include the replication, by several states and territories, of anti-organised crime legislation known to be valid but arguably not best policy: see Gabrielle Appleby, 'The High Court and Kable: A Study in Federalism and Rights Protection' (2014) 40 Monash University Law Review 673; and amendments made shortly before the passage of the Australian Citizenship Amendment (Allegiance to Australia) Act 2015 (Cth) (see Commonwealth Parliamentary Debates, Senate, 1 December 2015, 9508).

12 Mark Tushnet, 'Policy Distortion and Democratic Debilitation: Comparative Illumination of the Countermajoritarian Difficulty' (1995) 94 Michigan Law Review 245. 
is responsive and tailored to the needs of the community, whether it is proportionate, whether human rights concerns are addressed, and whether it is likely to be effective.

\section{Two Proposed Reforms}

At present, Australian parliamentarians may gain assistance from a number of sources of advice on questions of constitutional validity. But in no Australian jurisdiction is there a dedicated constitutional legal adviser available for parliamentarians or parliamentary committees to access.

Parliamentarians most frequently rely upon the assurances or summaries provided by the government regarding its constitutional advice, often received from the Solicitor-General; and the submissions of constitutional experts to parliamentary committee inquiries. In this part, we identify shortcomings of these sources and propose two reforms to address them.

There is now an established practice that the government will release a summary or assurance about legal advice it has received, but not disclose the full advice. The practice rests not on assertions of legal professional privilege - which is not a valid ground on which to refuse to produce documents to the parliament following Egan $v$ Chadwick $^{13}$ - but on practice and convention. ${ }^{14}$ Pursuant to now established convention, parliament refrains from exercising its powers to require the production of government legal opinions on the basis that there is a strong public interest in maintaining the confidentiality of government legal advice.

It is our view that the adherence to the convention has gone too far, at least insofar as it applies to advice relating to legislative proposals in areas of constitutional uncertainty. In these situations, the government is asking the parliament to be complicit in an action that raises constitutional risk. We argue that, where the proposal raises unresolved and complex constitutional questions, the public interest in disclosing government legal advice on constitutional validity to the parliament outweighs the public interest in maintaining confidentiality in the legal advice. Full disclosure of advice on constitutional risk would allow parliamentarians

13 Egan v Chadwick (1999) 46 NSWLR 563.

14 See further discussion of the convention in Australia in Anthony Mason, 'The Parliament, the Executive and the Solicitor-General' in Gabrielle Appleby, Patrick Keyzer and John Williams (eds), Public Sentinels: A Comparative Study of Australian Solicitors-General (Ashgate, 2014) 49, 65. 
to assess the factual assumptions that underpin the advice and understand the subtleties and nuance of the advice and any qualifications contained in it, or degrees of confidence in which it is expressed. ${ }^{15}$ This would facilitate (although of course not guarantee) deliberation of the type that we have argued parliamentarians ought to engage in as responsible constitutional actors. Of course, full public disclosure of this advice might be limited sometimes by legitimate public interest claims over certain parts of the advice - for example, parts that might raise national security issues or matters of Cabinet confidentiality. There might also be legitimate reasons that the government wishes to maintain legal professional privilege over the advice, and, as such, arrangements might need to be made to ensure that the release to parliamentarians is done in such a way as to not waive this privilege.

The second source of constitutional advice frequently relied upon by parliamentarians is submissions and evidence from experts - academics, professional legal associations and legal practitioners. Such submissions and evidence will often give rise to a range of different opinions on the same issue. This we actually see as desirable: it gives parliamentarians a sense of the complexity and nuance of particular constitutional issues. It reflects the reality that there is often no easy or single resolution to most constitutional questions.

However, there are a number of shortcomings with parliamentary reliance on such submissions. The first is that the number, spread and quality of submissions will differ depending on who has time, inclination and expertise to make a submission to a committee inquiry. Second, while submissions are often of extremely high quality written by the foremost experts in the field, they are not a direct substitute for legal advice. They are often prepared under extraordinary time pressures. They will often lack the inside factual knowledge that a full legal consideration of the issue requires. The author of the submission, rather than the parliament, will determine which issues to address.

15 See similar arguments in Harold Koh, 'Protecting the Office of Legal Counsel from Itself' (1994) 15 Cardozo Law Review 513, 51. 
We therefore suggest a second reform: the appointment of a dedicated office of 'Counsel to the Parliament', specialising in constitutional and public law, to advise individual parliamentarians and parliamentary committees. The appointee should be a leading constitutional lawyer, with expertise comparable to that of the Solicitor-General.

What is the relationship between the two reform proposals? Is it preferable to implement one or the other, or both? To facilitate and properly equip parliamentarians to engage in best possible practice in relation to legislative deliberation regarding constitutional norms, both reforms ought to be adopted. (Although, we should add, the adoption of only one or the other would still be preferable to the current position.) The government's legal advice is likely to be informed by a more complete factual picture than that which might be provided by Counsel to the Parliament, simply because of the wider factual matrix likely to be available to the government and their advisers. There is also a possibility that the two officers will come to different positions on the constitutional questions, will assess the degree of constitutional risk at different levels, or will formulate and analyse different alternative proposals that might address the identified constitutional risks. Such differences would inform and assist parliamentary deliberation about the questions that we have argued are relevant for responsible constitutional engagement. Finally, we would say it is important that parliament has available to it dedicated constitutional counsel with whom it has a professional lawyer-client relationship because this allows parliamentarians to direct the advice received: to consider, for example, specific provisions or possible alternative formulations to the proposed provisions and do relative constitutional risk assessments. 
This text is taken from New Directions for Law in Australia: Essays in Contemporary Law Reform, edited by Ron Levy, Molly O’Brien, Simon Rice, Pauline Ridge and Margaret Thornton, published 2017 by ANU Press, The Australian National University, Canberra, Australia. 